\title{
Corn yield, forage production and quality affected by methods of intercropping corn and Panicum maximum
}

\author{
Rodrigo Estevam Munhoz de Almeida(1), Caio Macret Gomes ${ }^{(2)}$, Bruno Cocco Lago(2), \\ Silas Maciel de Oliveira ${ }^{(2)}$, Clovis Pierozan Junior ${ }^{(3)}$ and José Laércio Favarin ${ }^{(2)}$
}

\begin{abstract}
(1)Embrapa Pesca e Aquicultura, Prolongamento da Avenida NS 10, Cruzamento com a Avenida LO 18, Sentido Norte, s/no, Loteamento Água Fria, CEP 77008-900 Palmas, TO, Brazil. E-mail: rodrigo.almeida@embrapa.br (2)Universidade de São Paulo, Escola Superior de Agricultura Luiz de Queiroz, Avenida Pádua Dias, no 11, Caixa Postal 9, CEP 13418-900 Piracicaba, SP, Brazil. E-mail: caio.macret.gomes@usp.br, bruno.cl@hotmail.com, silasmaciel2000@hotmail.com, favarin.esalq@usp.br ${ }^{(3)}$ Instituto Federal do Paraná, Campus Palmas, Avenida Bento Munhoz da Rocha Neto, s/no, PRT-280, Trevo da Codapar, CEP 85555-000 Palmas, PR, Brazil. E-mail: clovis.junior@ifpr.edu.br
\end{abstract}

\begin{abstract}
The objective of this work was to evaluate methods of intercropping corn and Panicum spp. forages and their effects on corn yield and forage development. Two experiments with Panicum spp. were conducted, one with 'Tanzania' and other with 'Massai' in the municipality of Piracicaba, in the state of São Paulo, Brazil, in the 2012/2013 growing season. In both experiments, the treatments were: broadcast seeding of Panicum spp. at the same time of corn sowing; corn with Panicum spp. between rows; Panicum spp. sown with fertilizer; Panicum spp. sown between corn rows after corn establishment; broadcast seeding of Panicum spp. after corn establishment; and sole corn sowing. For corn, leaf nitrogen content, ear height, and grain yield were evaluated. For Panicum spp. cultivars, height, dry mass, tiller density, and leaf:stem ratio were evaluated. The intercropping establishment methods used do not affect corn growth, grain yield, and $\mathrm{N}$ leaf content. The seeding of both cultivars of Panicum spp. when corn plants had four expanded leaves reduces forage dry mass production and increases the leaf:stem ratio. The Panicum spp. broadcast method, performed after corn was established, does not allow appropriate establishment, with few plants in the area.
\end{abstract}

Index terms: Zea mays, guinea grass, interspecific competition, tropical perennial grass.

\section{Produtividade de milho, produção e qualidade de forragem afetadas pelos métodos de consórcio do milho com Panicum maximum}

\begin{abstract}
Resumo - O objetivo deste trabalho foi avaliar métodos de implantação do consórcio milho e espécies forrageiras de Panicum spp. e os efeitos na produtividade do milho e no desenvolvimento das forragens. Dois experimentos com Panicum spp. foram conduzidos, um com 'Tanzania' e outro com 'Massai' em Piracicaba, SP, na safra 2012/2013. Em ambos os experimentos, os tratamentos foram: Panicum spp. semeado a lanço no momento da semeadura do milho; milho com Panicum spp. nas entrelinhas; Panicum spp. semeado com fertilizante; Panicum spp. semeado nas entrelinhas depois do estabelecimento do milho; Panicum spp. semeado a lanço depois do estabelecimento do milho; e milho solteiro. Para o milho, avaliaram-se a concentração de nitrogênio foliar, a altura de espigas e a produtividade de grãos. Para as cultivares de Panicum spp., avaliaram-se altura, massa seca, número de perfilhos e relação folha:colmo. Os métodos de implantação do consórcio avaliados não afetam o crescimento, a produtividade de grãos e a concentração foliar de $\mathrm{N}$ do milho. A implantação das cultivares de Panicum spp., quando o milho apresenta quatro folhas expandidas, reduz a massa seca e aumenta a relação folha:colmo das plantas forrageiras. A semeadura a lanço de Panicum spp., depois do estabelecimento do milho, não permite o estabelecimento adequado, com poucas plantas na área.
\end{abstract}

Termos para indexação: Zea mays, capim 'Tanzania', competição interespecífica, gramínea perene tropical.

\section{Introduction}

Integrated crop-livestock system (ICL) attends the guidelines to obtain a sustainable management of the crop and animal production. The ICL can synthesize many benefits: increase soil fertility (Zhang \& Li,
2003; Tracy \& Zhang, 2008; Ochsner et al., 2010) and nutrient cycling (Baributsa et al., 2008; Garcia et al., 2008; Lithourgidis et al., 2011), contributing to improve physical and biological attributes of the soil (Acosta-Martínez et al., 2004; Qin et al., 2013). 
Different ways of deploying ICL can be used (Borgui et al., 2013). However, most farms in South America have cultivated the fields with annual crops for years, then, moved on to intercropping between maize and tropical grass (Borgui et al., 2013). After the harvest of the annual crop, fields can be grazed by the livestock (Crusciol et al., 2015).

Panicum spp. have a larger forage production compared to Urochloa species (Silva et al., 2016). This is an important feature to animal grazing after corn harvest in ICL systems, since a larger number of animals can graze the field. In the other hand, Panicum spp. sward erected leaves structure, and bigger height (Mello \& Pedreira, 2004) may pose a problem to interspecific competition. If Panicum spp. species were not suppressed by corn, surely corn grain yield would be lower at intercropping.

Considering this, an important issue is the intercropping establishment method between corn and Panicum spp. cultivars. Due to differences of seeders and farm sizes, tropical grasses sowing have been done before, simultaneously or after corn sowing (Borgui et al., 2013). The intercropping between corn and palisadegrass showed that grass sowing simultaneously or after corn has no effect on grain yield (Borghi et al., 2013), with the right herbicide management for this system (Ceccon et al., 2010). However, the pasture production was decreased by $20 \%$ when tropical grass was sown after corn planting (Borghi et al., 2013). So, more information about corn and Panicum spp. grass intercropping is necessary. Doubts about grain yield, $\mathrm{N}$ uptake, as well as about the perennial crop forage biomass yields and biomass quality should be elucidated.

The objective of this work was to evaluate the most common methods of intercropping systems with Panicum spp. cultivars and their effects on grain yield and grass development.

\section{Materials and Methods}

Two independent experiments were conducted in 2012/2013, in municipality of Piracicaba, state of São Paulo, Brazil, 22 $41^{\circ} 31^{\prime \prime S}, 47^{\circ} 38^{\prime} 00^{\prime \prime} \mathrm{W}$ and $580 \mathrm{~m}$ of altitude. Precipitation and temperature of the experimental period are presented on Figure 1. Intercropping between corn and Panicum spp. was established on a Typic Hapludults soil (USDA, 2006).
Before starting the experiment, a chemical analysis of the soil (Raij et al., 2001) was performed in the 0.0 $0.2 \mathrm{~m}$ layer, providing the following results: $\mathrm{pH} 5.3$ $\left(\mathrm{CaCl}_{2}\right)$; organic matter $24 \mathrm{~g} \mathrm{dm}^{-3} ; \mathrm{P} 21 \mathrm{mg} \mathrm{dm}^{-3}$ (resin extractor); $\mathrm{K}, \mathrm{Ca}, \mathrm{Mg}$ and potential acidity at pH 7.0 $(\mathrm{H}+\mathrm{Al})$ of 2.7, 3.7, 1.8 and $3.4 \mathrm{cmol}_{\mathrm{c}} \mathrm{dm}^{-3}$, respectively, with a base saturation of $63 \%$. Cultivar used in experiment one was 'Tanzania' grass [Panicum maximum Jacq. (Syn. Megathyrsus maximus (Jacq.) B.K.Simon \& S.W.L.Jacobs)], and in the experiment two, the hybrid 'Massai' grass (Panicum maximum $\mathrm{x}$ Panicum infestum).

In both experiments, intercropping methods were compared between 6 treatments: Panicum spp. broadcast seeding aboveground 1 hour before corn sowing (S. broadcast); simultaneously plant sowing with Panicum spp. seeds distributed in furrow between corn rows (S. between rows); simultaneously plant sowing in same row with Panicum spp. seeds in corn fertilizer depth (S. Fertilizer); Panicum spp. seeds distributed in furrow between corn rows concomitantly with top dressing fertilization at 4-leaf corn stage (T. between rows); Panicum spp. broadcast sowing with top dressing fertilization at 4-leaf corn stage (T. broadcast); sole corn cultivation. Experimental design for both trials was randomized blocks with 4 replications. Plots had $3.6 \mathrm{~m}$ (4 corn rows) per $10 \mathrm{~m}$ length and the total area of each trial was $864 \mathrm{~m}^{2}$.

Both Panicum spp. cultivars were sown at the density of $2.4 \mathrm{~kg} \mathrm{ha}^{-1}$ of viable seeds in all treatments. To $\mathrm{S}$. between rows and $\mathrm{T}$. between rows treatments, the seeds were sown in a furrow with $0.03 \mathrm{~m}$ depth to simulate the seeder or the conventional fertilizer spreader. In S. fertilizer treatment, adjacent furrows to corn rows were made with $0.06 \mathrm{~m}$ depth. This procedure simulated what occurs when forage seeds are mixed with corn fertilizer and sown in the same operation; on the other hand, eventual salinity provided by seedfertilizer contact was not included in this research.

The hybrid AG 8061 PRO was sown in both experiments on 12th of December, 2012, with 0.9 $\mathrm{m}$ row spacing, aiming at 60,000 plants $\mathrm{ha}^{-1}$. The sowing fertilizer consisted of 27; 87; and $50 \mathrm{~kg} \mathrm{ha}^{-1}$ of $\mathrm{N}, \mathrm{P}_{2} \mathrm{O}_{5}$ and $\mathrm{K}_{2} \mathrm{O}$, respectively. At corn stage of four expanded leaves, topdressing fertilization was applied (100 kg ha-1 of $\mathrm{N}$ and $30 \mathrm{~kg} \mathrm{ha}^{-1}$ of $\mathrm{K}_{2} \mathrm{O}$ ).

At corn stage of three expanded leaves and grasses with at least one tiller, $3.5 \mathrm{~kg} \mathrm{ha}^{-1}$ of atrazine 
(6-chloro- $\mathrm{N}^{2}$-ethyll-N4-isopropyl-1,3,5-triazine-2,4diamine) and $150 \mathrm{ml} \mathrm{ha} \mathrm{ha}^{-1}$ of mesotrione [2-(4-mesyl2-nitrobenzoyl)cyclohexane-1,3-dione] were applied with a spray volume of $250 \mathrm{~L} \mathrm{ha}^{-1}$ to control weeds. The mesotrione was used to delay the Panicum spp. grow th and to keep corn competitive advantage relative to forage. It was applied in all treatments, however, before Panicum spp. sowing for T. between rows and T. broadcast treatments.

Corn leaf sampling for $\mathrm{N}$ concentration analysis was done when $50 \%$ of the corn plants were in full flowering stage. Corn leaf sampling was randomized by choosing 5 plants per plot as methodology proposed by Malavolta et al. (1997). N concentration in leaf samples was determined using methods described by Malavolta et al. (1997).

Just prior to crop harvest, the corn first ear insertion height was measured in two central rows of each plot. Grain yield was determined harvesting ears of $4 \mathrm{~m}$ long lines from two central rows. Threshed grains were weighted, the moisture content was determined, and the data was transformed to grain yield per hectare (130 $\mathrm{g} \mathrm{kg}^{-1}$ wet basis).

In order to evaluate Panicum spp. cultivars 'Tanzania' and 'Massai', tiller density was measured by counting a number of tillers inside a $0.25 \mathrm{~m}^{2}$ area in the center of each plot defined by a frame. Dry mass production was determined by cutting the grass inside

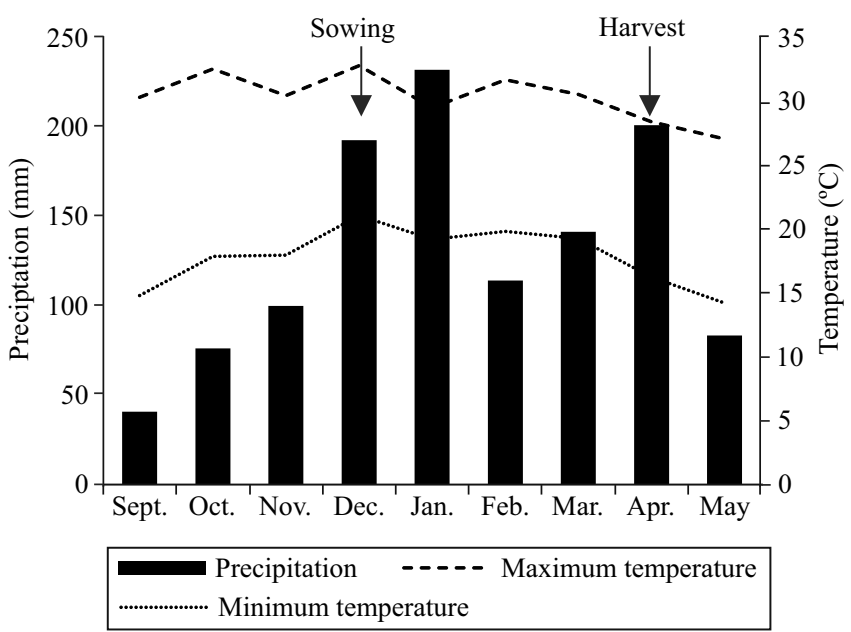

Figure 1. Precipitation, maximum temperature and minimum temperature at Piracicaba, state of São Paulo, from 2012/2013 growing season. a frame of $1 \mathrm{~m}^{2}$. The leaf:stem ratio was measured with a subsample, which was dissected into leaves, stem and dead material. All the material was dried in a ventilated laboratory oven at $65^{\circ} \mathrm{C}$ for 72 hours for dry mass determination. All samples were obtained on the same day of the corn harvesting.

Data was submitted to test for normality and homogeneity of variance. If these requirements were confirmed, an analysis of variance would be applied to verify if the effects were caused by the intercropping methods. Means were compared by Fisher test (LSD) $\mathrm{p} \leq 0.05$. The statistical analysis was done using SAS software (SAS Institute Inc., Cary, NC, USA).

\section{Results and Discussion}

The methods for establishing grasses did not affect the height of ear - which was in average $1.25 \mathrm{~m}$ for both experiments -, grain yield (Table 1) or $\mathrm{N}$ concentration in leaves (Table 2).

The height of the corn ear insertion is important as a morphologic change induced by low intensity or different quality of light (Rajcan \& Swanton, 2001). Therefore, in this study, it was possible to infer that grasses do not impair corn growth. Borghi et al. (2013) observed no differences in height of ear when two methods for intercropping corn and tropical grasses were compared to corn monoculture.

Table 1. Height of ear (m) and grain yield with $13 \%$ of humidity $\left(\mathrm{kg} \mathrm{ha}^{-1}\right)$ in an intercropping system between corn and Panicum spp.

\begin{tabular}{lccccc}
\hline $\begin{array}{l}\text { Establishment } \\
\text { methods }(\mathrm{EM})^{(1)}\end{array}$ & \multicolumn{2}{c}{ Height of ear $(\mathrm{m})$} & & \multicolumn{2}{c}{ Grain yield (kg ha-1) } \\
\cline { 2 - 3 } \cline { 5 - 6 } S. broadcast & 'Tanzania' & 'Massai' & & 'Tanzania' & 'Massai' \\
\hline S. between rows & 1.23 & 1.26 & & 6,965 & 6,638 \\
S. fertilizer & 1.25 & 1.23 & & 6,407 & 6,710 \\
T. between rows & 1.24 & 1.25 & & 7,495 & 5,994 \\
T. broadcast & 1.24 & 1.26 & & 7,384 & 6,135 \\
Sole corn & 1.26 & 1.22 & & 7,496 & 7,161 \\
\hline Mean & 1.25 & 1.26 & & 7,560 & 6,601 \\
\hline EM & $0.9550^{\mathrm{ns}}$ & $0.7793^{\mathrm{ns}}$ & & $0.8057^{\mathrm{ns}}$ & $0.5690^{\mathrm{ns}}$ \\
CV $(\%)$ & 3.58 & 3.74 & & 13.88 & 14.45 \\
\hline
\end{tabular}

${ }^{(1)}$ S. broadcast: Panicum spp. broadcast seeding before corn sowing; S. between rows: Panicum spp. seeds distributed in furrow between corn rows; S. fertilizer: Panicum spp. seeds in corn sowing fertilizer depth; T. between rows: Panicum spp. in furrow between corn rows at top dressing fertilization; T. broadcast: Panicum spp. broadcast sowing with top dressing fertilization; Sole corn: corn without Panicum spp. ${ }^{\text {ns Nonsignificant }}$ by the F test. 
Grain yield was the same for intercropped treatments and sole corn cultivation in both experiments and it was, in average, 7,218 $\mathrm{kg} \mathrm{ha}^{-1}$ for 'Tanzania' cultivar and $6,540 \mathrm{~kg} \mathrm{ha}^{-1}$ for 'Massai' (Table 1). These observations prove the viability of intercropping corn and Panicum spp. grasses in crop and livestock integration systems as reported to other kind of tropical grasses (Baldé et al., 2011; Borghi et al., 2013; Ceccon et al., 2013).

Corn leaf $\mathrm{N}$ content at flowering was not affected by the method for establishing grasses, which was in average $34 \mathrm{~g} \mathrm{~kg}^{-1}$ for both experiments (Table 2). $\mathrm{N}$ concentration in leaves was higher than the level considered adequate, which is 27.5 to $32.5 \mathrm{~g} \mathrm{~kg}^{-1}$ (Malavolta et al., 1997). Therefore, it is presumed that the cultivation of Panicum spp. grasses with corn did not reduce the amount of available $\mathrm{N}$ in soil to affect $\mathrm{N}$ uptake by corn plants. Crusciol et al. (2013) also found no difference in leaf $\mathrm{N}$ content when sole corn cultivation was compared to intercropped corn and Urochloa sp.

Height, dry mass production, tiller density and leaf:stem ratio of the Panicum spp. cultivars were affected by intercropping methods (Tables 3 and 4). Both cultivars ('Tanzania' and 'Massai') had the same response to the different methods. Grasses sown right before or during the corn seeding (S. broadcast, $\mathrm{S}$. between rows and $\mathrm{S}$. fertilizer) reached greater height and produced more dry mass as well (Table 3).

Table 2. Corn leaf N content intercropped with Panicum spp. at the corn flowering.

\begin{tabular}{lcc}
\hline Establishment & \multicolumn{2}{c}{ Leaf N content $\left(\mathrm{g} \mathrm{kg}^{-1}\right)$} \\
\cline { 2 - 3 } methods (EM) $)^{(1)}$ & 'Tanzania' & 'Massai' \\
\hline S. broadcast & 34.5 & 34.1 \\
S. between rows & 32.8 & 33.6 \\
S. fertilizer & 34.7 & 34.0 \\
T. between rows & 33.4 & 34.9 \\
T. broadcast & 35.2 & 33.9 \\
Sole corn & 33.1 & 34.6 \\
\hline Mean & 33.9 & 34.2 \\
\hline EM & $0.6019^{\text {ns }}$ & $0.9910^{\text {ns }}$ \\
CV $(\%)$ & 5.68 & 7.84 \\
\hline
\end{tabular}

${ }^{(1)}$ S. broadcast: Panicum spp. broadcast seeding before corn sowing; S. between rows: Panicum spp. seeds distributed in furrow between corn rows; S. fertilizer: Panicum spp. seeds in corn sowing fertilizer depth; T. between rows: Panicum spp. in furrow between corn rows at top dressing fertilization; T. broadcast: Panicum spp. broadcast sowing with top dressing fertilization; Sole corn: corn without Panicum spp. ${ }^{\text {ns Nonsignificant }}$ by the $\mathrm{F}$ test.
Panicum spp. height, when sown after corn (T. between rows and T. broadcast), was lower ( $51 \%$ for 'Tanzania' and $56 \%$ for 'Massai') than in establishing methods on the same day of corn. The dry mass production was 3,995 $\mathrm{kg} \mathrm{ha}^{-1}$ for 'Tanzania' and $1,638 \mathrm{~kg} \mathrm{ha}^{-1}$ for 'Massai' when established on the same day of corn; and $479 \mathrm{~kg} \mathrm{ha}^{-1}$ for 'Tanzania' and $282 \mathrm{~kg} \mathrm{ha}^{-1}$ for 'Massai' when the grass was sown in furrow after corn germination ( $\mathrm{T}$. between rows), $86 \%$ lower than in the first treatments. On the other hand, the treatment T. broadcast produced only $85 \mathrm{~kg} \mathrm{ha}^{-1}$ and $27 \mathrm{~kg} \mathrm{ha}^{-1}$ of dry mass, for 'Tanzania' and 'Massai' respectively, and it was the less productive treatment (Table 3).

Panicum spp. dry mass production, when it was sown together with corn, was higher than in topdressing treatments because the initial growth of the grasses was prior to the shading by corn plants, and thus, the grasses had more incidence of light and development time on the beginning. Ferreira et al. (2010) reported shading affecting Panicum spp. dry mass production, and Borghi et al. (2013) observed higher dry mass production of tropical grasses when seeded simultaneously with corn compared to later sowing.

Low dry mass production, when Panicum spp. cultivars were broadcast sown at topdressing fertilization (T. broadcast), is explained by the lower plant population. This stablishing method provided 60

Table 3. Height $(\mathrm{m})$ and dry mass production $\left(\mathrm{kg} \mathrm{ha}^{-1}\right)$ of Panicum spp. cv. Tanzania and cv. Massai intercropped with $\operatorname{corn}^{(1)}$.

\begin{tabular}{lccccc}
\hline \multirow{2}{*}{$\begin{array}{l}\text { Establishment } \\
\text { methods (EM) }\end{array}$} & \multicolumn{2}{c}{ Height $(\mathrm{m})$} & & \multicolumn{2}{c}{ Dry mass $\left(\mathrm{kg} \mathrm{ha}^{-1}\right)$} \\
\cline { 2 - 3 } \cline { 5 - 6 } & 'Tanzania' & 'Massai' & & 'Tanzania' & 'Massai' \\
\hline S. broadcast & $1.54 \mathrm{a}$ & $1.35 \mathrm{a}$ & & $4,050 \mathrm{a}$ & $1,848 \mathrm{a}$ \\
S. between rows & $1.58 \mathrm{a}$ & $1.25 \mathrm{a}$ & & $4,032 \mathrm{a}$ & $1,613 \mathrm{ab}$ \\
S. fertilizer & $1.42 \mathrm{a}$ & $1.17 \mathrm{a}$ & & $3,903 \mathrm{a}$ & $1,453 \mathrm{~b}$ \\
T. between rows & $0.81 \mathrm{~b}$ & $0.62 \mathrm{~b}$ & & $479 \mathrm{~b}$ & $282 \mathrm{c}$ \\
T. broadcast & $0.72 \mathrm{~b}$ & $0.50 \mathrm{~b}$ & & $85 \mathrm{c}$ & $27 \mathrm{~d}$ \\
\hline Mean & 1.21 & 1.01 & & 2,510 & 1,045 \\
\hline EM & $<0.0001^{* * *}$ & $<0.0001^{* * *}$ & $<0.0001^{* * *}$ & $<0.0001^{* * *}$ \\
CV (\%) & 17.17 & 6.68 & & 13.31 & 20.54 \\
\hline
\end{tabular}

${ }^{(1)}$ Means followed by the same letter in the columns do not differ by LSD test at $5 \%$ probability. ${ }^{(2)}$ S. broadcast: Panicum spp. broadcast seeding before corn sowing; S. between rows: Panicum spp. seeds distributed in furrow between corn rows; S. fertilizer: Panicum spp. seeds in corn sowing fertilizer depth; T. between rows: Panicum spp. in furrow between corn rows at top dressing fertilization; T. broadcast: Panicum spp. broadcast sowing with top dressing fertilization. ${ }^{* *}$ Significant at less than $0.1 \%$ probability of error by the F test.

Pesq. agropec. bras., Brasília, v.52, n.3, p.170-176, mar. 2017 DOI: 10.1590/S0100-204X2017000300004 
and 147 tillers $\mathrm{m}^{-2}$ for 'Tanzania' and 'Massai' grasses respectively, $71 \%$ or $64 \%$ less than the average of other treatments, which had 211 tillers $\mathrm{m}^{-2}$ for 'Tanzania' and 412 tillers $\mathrm{m}^{-2}$ for 'Massai' (Table 4). Grass seed incorporation in soil is crucial for good plant establishment (Freitas et al., 2005). Therefore, it is not recommended to establish the intercropping with broadcast seeding after the corn plant development. For the other treatment of broadcast seeding of Panicum spp. before corn (S. broadcast), this fact did not occur because the seeder, when working after grass seed distribution, provided the necessary seed incorporation.

The leaf:stem ratio data was higher when grasses were sown after corn germination ( $\mathrm{T}$. broadcast and $\mathrm{T}$. between rows). When the grasses were sown simultaneously with corn (S. broadcast, S. between rows and S. fertilizer), the ratio was $64 \%$ lower than in the other methods for 'Tanzania' and 61\% lower for 'Massai' (Table 4). The earlier grass establishment in S. broadcast, S. between rows, and S. fertilizer influenced the pattern of growth. In such cases, the grass developed greater height and consequent lower leaf:stem ratio. Several studies positively correlate height growth of grasses with elongation of stems and consequent lower leaf:stem ratio, which is attributed

Table 4. Tiller density (number $\mathrm{m}^{-2}$ ) and leaf:stem ratio of Panicum spp. cv. Tanzania and cv. Massai intercropped with $\operatorname{corn}^{(1)}$.

\begin{tabular}{lccccc}
\hline Establishment & \multicolumn{2}{c}{ Tiller density $\left(\mathrm{n}^{\mathrm{o}} \mathrm{m}^{-2}\right)$} & & \multicolumn{2}{c}{ Leaf:stem ratio } \\
\cline { 2 - 3 } \cline { 5 - 6 } methods $(E M)^{(2)}$ & 'Tanzania' & 'Massai' & & 'Tanzania' & 'Massai' \\
\hline S. broadcast & $187 \mathrm{a}$ & $475 \mathrm{a}$ & & $0.51 \mathrm{~b}$ & $1.13 \mathrm{bc}$ \\
S. between rows & $235 \mathrm{a}$ & $423 \mathrm{a}$ & & $0.43 \mathrm{~b}$ & $1.34 \mathrm{ab}$ \\
S. fertilizer & $235 \mathrm{a}$ & $436 \mathrm{a}$ & & $0.72 \mathrm{~b}$ & $0.90 \mathrm{c}$ \\
T. between rows & $189 \mathrm{a}$ & $314 \mathrm{ab}$ & & $1.44 \mathrm{a}$ & $2.59 \mathrm{a}$ \\
T. broadcast & $60 \mathrm{~b}$ & $147 \mathrm{~b}$ & & $1.60 \mathrm{a}$ & $3.15 \mathrm{a}$ \\
\hline Mean & 181 & 370 & & 0.94 & 1.82 \\
\hline EM & $0.0045^{* *}$ & $0.0027^{* *}$ & & $0.0005^{* *}$ & $0.0021^{* *}$ \\
$\mathrm{CV}(\%)$ & 10.33 & 7.68 & & 9.23 & 23.75 \\
\hline
\end{tabular}

(1)Means followed by the same letter in the columns do not differ by LSD test at $5 \%$ probability. ${ }^{(2)}$ S. broadcast: Panicum spp. broadcast seeding before corn sowing; S. between rows: Panicum spp. seeds distributed in furrow between corn rows; S. fertilizer: Panicum spp. seeds in corn sowing fertilizer depth; T. between rows: Panicum spp. in furrow between corn rows at top dressing fertilization; T. broadcast: Panicum spp. broadcast sowing with top dressing fertilization; Sole corn: Corn without Panicum spp. ${ }^{* *}$ Significant at less than $1 \%$ probability of error by the $\mathrm{F}$ test. to competition between tillers per light (Sbrissia \& Silva, 2008). Paciullo et al. (2011) observed higher stem elongation rate in three species of Urochloa sp. by decreasing the intensity of available light.

Recommended pre-grazing height of 'Tanzania' pasture is $0.75 \mathrm{~m}$, which corresponds to $95 \%$ of sunlight interception and higher dry mass production of leaf lamina associated with the control of stem elongation (Zanine et al., 2011). 'Tanzania' height, when seeded simultaneously with corn, was $1.51 \mathrm{~m}$, which demonstrates that the grass exceeded the management goal because of the delay in its harvest due to the presence of the corn.

Treatments in which the grasses were sown after corn obtained suitable values of height, $0.76 \mathrm{~m}$ and $0.56 \mathrm{~m}$ for 'Tanzania' and 'Massai' respectively, and leaf:stem ratio 1.5 for 'Tanzania' and 2.9 for 'Massai' (Tables 3 and 4). This happened due to shorter development time during intercropping. Zanine et al. (2011) obtained leaf:stem ratio of 2.78 also with 'Tanzania' grass, adopting pre-grazing heights corresponding to $0.75 \mathrm{~m}$.

The elevated grass height related to the low quantity of dry mass of the 'Tanzania' and 'Massai' can also be explained by the greater influence of corn shading throughout development (Portes et al., 2000). The average height of 'Tanzania' grass sown on the same day as corn was $1.51 \mathrm{~m}$ whilst $0.8 \mathrm{~m}$ when sown after corn germination. The dry mass observed was only $3,995 \mathrm{~kg} \mathrm{ha}^{-1}$ for the methods for establishing on the same day as corn and $479 \mathrm{~kg} \mathrm{ha}^{-1}$ when 'Tanzania' was sown in furrow after corn. In an experiment in which 'Tanzania' cultivar was grazed at $0.75 \mathrm{~m}$, Zanine et al. (2011) obtained the herbage pre-grazing mass of $6,070 \mathrm{~kg} \mathrm{ha}^{-1}$.

The methods S. broadcast, S. between rows and S. fertilizer produced dry mass for grazing cattle in an integrated crop-livestock system, or for covering the soil for no-tillage cultivation of annual crops for the next growing season. Meanwhile, the long development period of the grass in these treatments favors the production of stems relative to leaves, especially in the case of the cultivar Tanzania. According to Valente et al. (2010), the leaf:stem ratio is positively correlated with digestibility of grass; and the high proportion of stem in the sward can limit animal intake (Gontijo Neto et al., 2006). The 'Massai' cultivar showed a lower proportion of stem, making it more suitable for simultaneous establishment with corn. 
T. between rows produced smaller amount of dry mass at corn harvest when compared to the simultaneous establishing methods of intercropping, and it can be used for soil cover or grazing in a period after corn harvest. According to Zhang \& Li (2003), grasses have additional growth after the main crop harvest.

\section{Conclusions}

1. The intercropping establishment methods used do not affect growing, grain yield, and $\mathrm{N}$ leaf content of corn when it is intercropped with both Panicum spp. cultivars.

2. The seeding of both cultivars of Panicum spp. when the corn plants had 4 expanded leaves reduces forage dry mass production, and increases leaf:stem ratio.

3. The broadcast seeding of the forage simultaneously to top dressing fertilization method is not feasible on the experimental conditions because the grass is not properly established, with few plants in the area.

\section{Acknowledgments}

To Conselho Nacional de Desenvolvimento Científico e Tecnológico (CNPq), to Coordenação de Aperfeiçoamento de Pessoal de Nível Superior (Capes), and to Fundação de Amparo à Pesquisa do Estado de São Paulo (Fapesp), for the scholarships granted.

\section{References}

ACOSTA-MARTÍNEZ, V.; ZOBECK, T.M.; ALLEN, V. Soil microbial, chemical and physical properties in continuous cotton and integrated crop-livestock systems. Soil Science Society of America Journal, v.68, p.1875-1884, 2004. DOI: 10.2136/ sssaj2004.1875.

BALDÉ, A.B.; SCOPEL, E.; AFFHOLDER, F.; CORBEELS, M.; SILVA, F.A.M. da; XAVIER, J.H.V.; WERY, J. Agronomic performance of no-tillage relay intercropping with maize under smallholder conditions in Central Brazil. Field Crops Research, v.124, p.240-251, 2011. DOI: 10.1016/j.fcr.2011.06.017.

BARIBUTSA, D.N.; FOSTER, E.F.; THELEN, K.D.; KRAVCHENKO, A.N.; MUTCH, D.R.; NGOUAJIO, M. Corn and cover crop response to corn density in an interseeding system. Agronomy Journal, v.100, p.981-987, 2008. DOI: 10.2134/ agronj2007.0110.

BORGUI, E.; CRUSCIOL, C.A.C.; MATEUS, G.P.; NASCENTE, A.S.; MARTINS, P.O. Intercropping time of corn and palisadegrass or guineagrass affecting grain yield and forage production. Crop Science, v.53, p.629-636, 2013. DOI: 10.2135/ cropsci2012.08.0469.

CECCON, G.; MATOSO, A.O.; NETO NETO, A.L.; PALOMBO, L. Uso de herbicidas no consórcio de milho safrinha com Brachiaria ruziziensis. Planta Daninha, v.28, p.359-364, 2010. DOI: $10.1590 / \mathrm{S} 0100-83582010000200015$.

CECCON, G.; STAUT, L.A.; SAGRILO, E.; MACHADO, L.A.Z.; NUNES, D.P.; ALVES, V.B. Legumes and forage species sole or intercropped with corn in soybean-corn succession in Midwestern Brazil. Revista Brasileira de Ciência do Solo, v.37, p.204-212, 2013. DOI: 10.1590/S0100-06832013000100021.

CRUSCIOL, C.A.C.; NASCENTE, A.S.; BORGHI, E.; SORATTO, R.P.; MARTINS, P.O. Improving soil fertility and crop yield in a tropical region with palisadegrass cover crops. Agronomy Journal, v.107, p.2271-2280, 2015. DOI: 10.2134/ agronj14.0603.

CRUSCIOL, C.A.C.; NASCENTE, A.S.; MATEUS, G.P.; BORGUI, E.; LELES, E.P.; SANTOS, N.C.B. Effect of intercropping on yields of corn with different relative maturities and palisadegrass. Agronomy Journal, v.105, p.599-606, 2013. DOI: 10.2134/agronj2012.0426.

FERREIRA, D.J.; ZANINE, A.M.; SOUTO, S.M.; DIAS, P.F. Capim tanzânia (Panicum maximum) sob sombreamento e manejo de corte. Archivos de Zootecnia, v.59, p.81-91, 2010. DOI: 10.4321/S0004-05922010000100009.

FREITAS, F.C.L.; FERREIRA L.R.; FERREIRA, F.A.; SANTOS, M.V.; AGNES, E.L.; CARDOSO, A.A.; JAKELAITIS, A. Formação de pastagem via consórcio de Brachiaria brizantha com o milho para silagem no sistema de plantio direto. Planta Daninha, v.23, p.49-58, 2005. DOI: 10.1590/S010083582005000100007.

GARCIA, R.A.; CRUSCIOL, C.A.C.; CALONEGO, J.C.; ROSOLEM, C.A. Potassium cycling in a corn-brachiaria cropping system. European Journal of Agronomy, v.28, p.579-585, 2008. DOI: 10.1016/j.eja.2008.01.002.

GONTIJO NETO, M.M.; EUCLIDES, V.P.B.; NASCIMENTO JÚNIOR, D. do; MIRANDA, L.F.; FONSECA, D.M. da; OLIVEIRA, M.P. de. Consumo e tempo diário de pastejo por novilhos Nelore em pastagem de capim-tanzânia sob diferentes ofertas de forragem. Revista Brasileira de Zootecnia, v.35, p.6066, 2006. DOI: 10.1590/S1516-35982006000100007.

LITHOURGIDIS, A.S.; VLACHOSTERGIOS, D.N.; DORDAS, C.A.; DAMALAS, C.A. Dry mass yield, nitrogen content, and competition in pea-cereal intercropping systems. European Journal of Agronomy, v.34, p.287-294, 2011. DOI: 10.1016/j. eja.2011.02.007.

MALAVOLTA, E.; VITTI, G.C.; OLIVEIRA, S.A. de. Avaliação do estado nutricional das plantas: princípios e aplicações. 2.ed. Piracicaba: Potafos, 1997.

MELLO, A.C.L. de; PEDREIRA, C.G.S. Respostas morfológicas do capim-tanzânia (Panicum maximum Jacq. cv. Tanzânia-1) irrigado à intensidade de desfolha sob lotação rotacionada. Revista Brasileira de Zootecnia, v.33, p.282-289, 2004. DOI: 10.1590/S1516-35982004000200003. 
OCHSNER, T.E.; ALBRECHT, K.A.; SCHUMACHER, T.W.; BAKER, J.M.; BERKEVICH, T.W. Water balance and nitrate leaching under corn in kura clover living mulch. Agronomy Journal, v.102, p.1169-1178, 2010. DOI: 10.2134/agronj2009.0523.

PACIULLO, D.S.C.; FERNANDES, P.B.; GOMIDE, C.A. de M.; CASTRO, C.R.T. de; SOUZA SOBRINHO, F. de; CARVALHO, C.A.B. de. The growth dynamics in Brachiaria species according to nitrogen dose and shade. Revista Brasileira de Zootecnia, v.40, p.270-276, 2011. DOI: 10.1590/S1516-35982011000200006.

PORTES, T. de A.; CARVALHO, S.I.C. de; OLIVEIRA, I.P. de; KLUTHCOUSKI, J. Análise do crescimento de uma cultivar de braquiária em cultivo solteiro e consorciado com cereais. Pesquisa Agropecuária Brasileira, v.35, p.1349-1358, 2000. DOI: 10.1590/ S0100-204X2000000700009.

QIN, A.-Z.; HUANG, G.B.; CHAI, Q.; YU, A.-Z.; HUANG, P. Grain yield and soil respiratory response to intercropping systems on arid land. Field Crops Research, v.144, p.1-10, 2013. DOI: 10.1016/j.fcr.2012.12.005.

RAIJ, B. van; ANDRADE, J.C. de; CANTARELLA, H.; QUAGGIO, J.A. (Ed.). Análise química para avaliação da fertilidade de solos tropicais. Campinas: IAC, 2001. 285p.

RAJCAN, I.; SWANTON, C.J. Understanding maize-weed competition: resource competition, light quality and the whole plant. Field Crops Research, v.71, p.139-150, 2001. DOI: 10.1016/ S0378-4290(01)00159-9.

SBRISSIA, A.F.; Da SILVA, S.C. da. Compensação tamanho/ densidade populacional de perfilhos em pastos de capim- marandu. Revista Brasileira de Zootecnia, v.37, p.35-47, 2008. DOI: $10.1590 / \mathrm{S} 1516-35982008000100005$.

SILVA, J. de L.; RIBEIRO, K.G.; HERCULANO, B.N.; PEREIRA, O.G.; PEREIRA, R.C.; SOARES, L.F.P. Massa de forragem e características estruturais e bromatológicas de cultivares de Brachiaria e Panicum. Ciência Animal Brasileira, v.17, p.342348, 2016. DOI: 10.1590/1089-6891v17i332914.

TRACY, B.F.; ZHANG, Y. Soil compaction, corn yield response, and soil nutrient pool dynamics within an integrated croplivestock system in Illinois. Crop Science, v.48, p.1211-1218, 2008. DOI: 10.2135/cropsci2007.07.0390.

USDA. United States Department of Agriculture. Keys to soil taxonomy. $10^{\text {th }}$ ed. Washington: Usda, 2006. 333p.

VALENTE, B.S.M.; CÂNDIDO, M.J.D.; CUTRIM JUNIOR, J.A.A.; PEREIRA, E.S.; BOMFIM, M.A.D.; FEITOSA, J.V. Composição químico-bromatológica, digestibilidade e degradação in situ da dieta de ovinos em capim-tanzânia sob três frequências de desfolhação. Revista Brasileira de Zootecnia, v.39, p.113-120, 2010. DOI: $10.1590 /$ S1516-35982010000100015.

ZANINE, A. de M.; NASCIMENTO JÚNIOR, D. do; SANTOS, M.E.R.; PENA, K. da S.; SILVA, S.C. da; SBRISSIA, A.F. Características estruturais e acúmulo de forragem em capimtanzânia sob pastejo rotativo. Revista Brasileira de Zootecnia, v.40, p.2364-2373, 2011. DOI: 10.1590/S1516-35982011001100012.

ZHANG, F.; LI, L. Using competitive and facilitative interactions in intercropping systems enhances crop productivity and nutrientuse efficiency. Plant and Soil, v.248, p.305-312, 2003. DOI: 10.1023/A:1022352229863.

Received on June 7, 2016 and accepted on November 3, 2016 